\title{
Irrigation to meet growing food demand with climate change, salinity and water trade
}

\author{
J. Connor ${ }^{1}$, K. Schwabe ${ }^{2}$ \& D. King ${ }^{1}$ \\ ${ }^{1}$ CSIRO Land and Water, Adelaide, Australia \\ ${ }^{2}$ University of California, Riverside, California, USA
}

\begin{abstract}
There is increasing demand for water due to rising world population and wealth. This, coupled with lower supplies of freshwater due to possible climate change, suggests further stress on an already over-allocated resource. Additionally, environmental concerns relating to low flow levels, and salinity may exacerbate the ability of irrigated agricultural regions to increase agricultural production. The objective of this research is to investigate the potential impacts of climate change induced water scarcity on irrigated agricultural productivity, water demand, and profitability. The extent to which output capacity is constrained by rising salinity levels and institutional regulating water trade are evaluated for a River Murray, Australia case study.
\end{abstract}

Keywords: irrigated agriculture, salinity, climate change, water scarcity.

\section{Introduction}

Recent trends in population growth, forecasting an average of nearly a billion more people every decade, suggest commensurate increases in food production will be required to meet future global demands. While the largest increases in food demand will occur in developing countries due to increases in both populations and daily calorie intake, the agricultural lands most capable of meeting these increases are likely to be located in developed countries, particularly the United States, with a sizeable increase in exports from Australia and Eastern Europe also likely (Anderson et al. [1]).

Given that the productivity of irrigated land is nearly three times greater than that of rain-fed land, significant increases in food production will most likely be met by expansion and intensification of irrigation, which currently produces over 
$40 \%$ of the world's food supply and uses approximately 60 to $80 \%$ of the world's freshwater supplies. Expansion and intensification of irrigated agriculture necessarily means large investments in irrigation infrastructure and, mostly likely, more water use. Increases in water use by irrigated agriculture for future food production will further stress a system that suffers from water scarcity presently. In addition, recent predictions from climate change models suggest further reductions in freshwater supplies in many of the already waterstressed semi-arid and arid regions worldwide.

Conceptually, allowing water to trade freely and independently of land should enhance the productivity of water in producing food and thus aid in meeting world food demand with irrigated crop production. In many parts of the world water rights are attached to land and not easily traded. Such property rights don't allow the flexibility or information signals required to guarantee allocation of water to highest value uses. The potential benefit of trade is that it allows dynamic re-allocation of water in response to changes in determinants of water value including evolving prices, technology and environmental conditions (Rosegrant [2]).

However, it has long been recognised that the economic case for free water trade is complicated by flow interdependencies. Trade not only reallocates water from low to high value uses, it can also reduce the reliability of third party water rights. This is the case in the Australian Murray Darling Basin (MDB), the focus of this case study. MDB water property rights holders can trade the entire quantity of water that they are entitled to divert. A result of this institutional rule and an increasingly active water market has been a tendency for irrigators to improve irrigation efficiency and sell water savings or use them to expand irrigated cropping. The net result is that less water flows down stream. In line with minimum flow maintenance rules, some of the lost flow is replaced with dam releases resulting in an erosion of the reliability of consumptive water rights. In addition the level of environmental flows in the MDB is reduced (Young and McColl [3]). In other part of the world (e.g. much of the western US) institutional rules to protect the reliability of third party water rights allow only the portion of a water property right that is consumptively used to be traded.

An additional flow interdependence issue arises because water trade may either improve or degrade water dependent environmental conditions. An important environmental concern in the River Murray case study considered here and many other major irrigated agricultural regions is salinity. As noted in Schwabe et al. [4], nearly one-third of the irrigated land worldwide is affected by salinization. Salinization inhibits the ability to intensify and expand irrigated lands through reducing crop yields. The fix - leaching salts out of the soil-leads to highly saline watertables and salt loading of water bodies. Both impacts can reduce crop yields. This research evaluates the impact of salinity on irrigated agriculture under alternative climate change scenarios.

The Murray-Darling Basin extends across one-seventh of the Australian continent, contains almost three-quarters of the irrigated land in Australia, and generates about $40 \%$ of national income derived from agriculture and grazing (MDBMC [5]). Extractions for irrigation, municipal and industrial use began in 
the late 1800 's and grew dramatically since the mid-1950s. As a result median annual flow to the sea is now only $27 \%$ of the pre-development flow and the frequency of moderate and large volume floods has decreased. Adverse environmental effects of the altered flow regime include algal blooms, and salinity risks of further die off of ecologically significant floodplain forests (Overton [6]). Additionally, lack of flow and saline fresh water mixing threatens the ecological health of the Ramsar-listed Coorong and Lower lakes estuaries at the mouth of River Murray.

The particular empirical application is the lower portion of the MurrayDarling River Basin (LMDB). The LMDB is currently experiencing historically unprecedented water allocation shortages while continually confronting increasing salinity in source water. Three sub-regions within the LMDB are considered in this study to gain insight into how regionally varying salinity levels and water allocation security influence the economics and food security impacts of climate change adaptation. As shown in Figure 1.

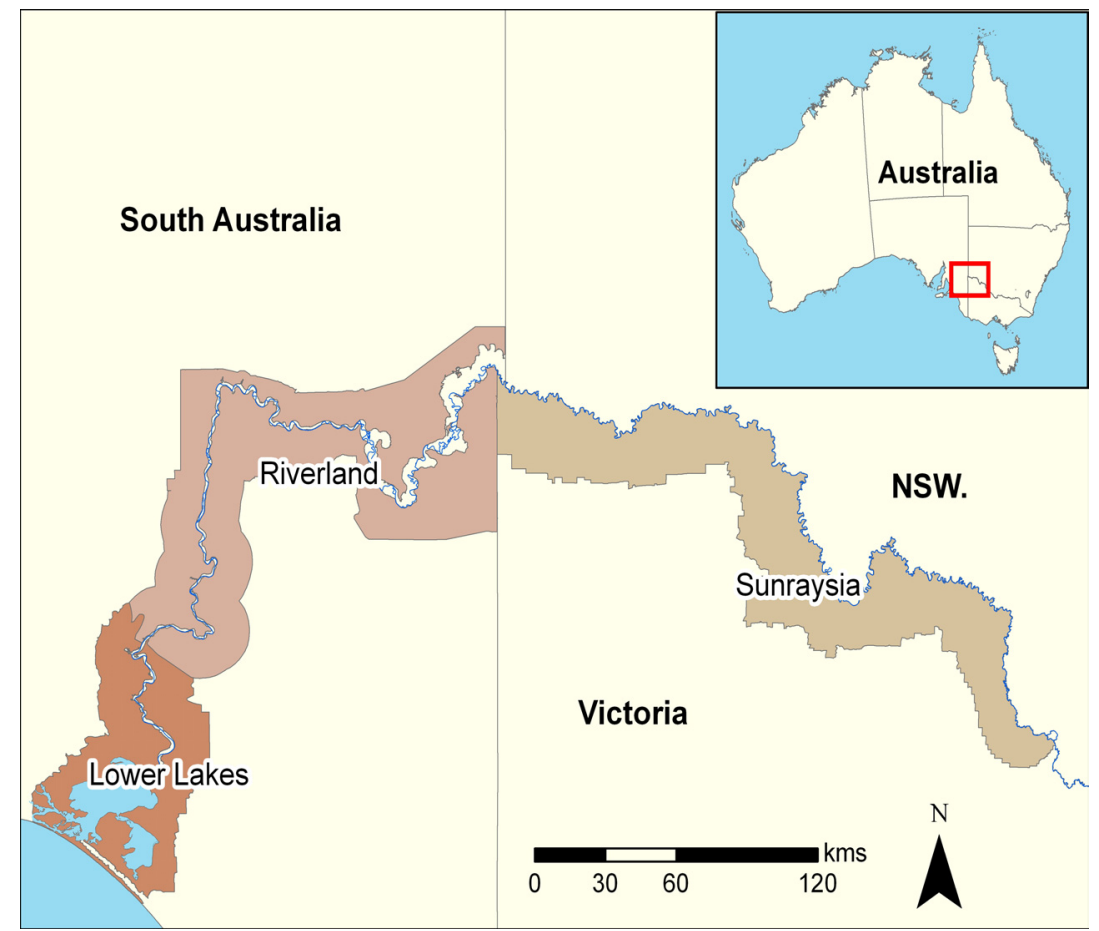

Figure 1: The Lower Murray Darling Basin river corridor, Australia.

The article reports on integrated hydro-economic optimisation modelling of:

1. Food supply and economic impacts of climate induced water scarcity with and without water markets

2. Food supply and economic impacts of salinity

3. Third party water right reliability and water quality (salinity) impacts 
Table 1 summarises parameter values that were varied across climate change scenarios and regions.

Table 1: $\quad$ Scenario summary.

\begin{tabular}{lccc}
\hline & Baseline climate & $\begin{array}{c}\text { Mild Climate } \\
\text { Change }\end{array}$ & $\begin{array}{c}\text { Moderate } \\
\text { Climate Change }\end{array}$ \\
\hline Temperature & Historical mean & 1 degree C & 2 degrees C \\
Average Annual & Historical mean & $5 \%$ decrease & $15 \%$ decrease \\
Rainfall & $1975-200025$ & & \\
& year reference & & \\
Average Annual & sequence levels & $13 \%$ decrease & $38 \%$ decrease \\
Basin Inflow & $\$ 53 / \mathrm{ML}$ & $\$ 164 / \mathrm{ML}$ & $\$ 250 / \mathrm{ML}$ \\
Average Water Price & 472 & & 372 \\
Average Annual Water Allocation $(\mathrm{GL})$ & 426 & 210 \\
Sunraysia & 342 & 272 & 59 \\
Riverland & 95 & 76 & 295 \\
Lower Lakes & 266 & & 502 \\
Average River Salinity $(\mu \mathrm{S} / \mathrm{cm})$ & 440 & 2209 \\
Sunraysia & 419 & 1618 & \\
Riverland & 1434 & & \\
Lower Lakes & & & \\
\hline
\end{tabular}

\section{Modelling flow, allocation, and salinity impacts of climate change}

The first step was estimation of potential impacts of climate change on river flow, salinity and water allocation. Impacts of climate change on water availability were modelled starting with a water use account developed to simulate rainfall-runoff partitioning, and basin in-flow for the Murray-Darling Basin. In-flows reductions were estimated for a mild and a moderate climate change scenario assuming average temperature increases across the region of 1 and 2 degrees Celsius, respectively. These climate scenarios are roughly consistent with the Australian Greenhouse Gas Office (AGO) predictions of a warming between 0.4 to 2.0 degrees Celsius in Australia by 2030. Water balance is maintained throughout the region with temperature increases resulting in lower rainfall and reductions in potential evapotranspiration (PET).

Basin inflow impacts consistent with these climate scenarios were predicted with the method developed by Kirby et al. [7] that involved partitioning rainfall between runoff and evapotranspiration (ET). The consequences of climate change on PET and rainfall are assumed to be felt uniformly across all rainfall events, both temporally and spatially.

The influence of climate change on water allocations to irrigation, river flow and salinity is determined by changes in in-flows given water allocation, dam storage 
rules, and flow management rules. For this analysis, water sharing rules consistent with the current Murray-Darling Basin Agreement are assumed and modelled with a basin river operation model known as Bigmod MSN. Bigmod MSN incorporates a daily flow and salinity mass balance model along with representations of all dam operating and water allocation rules governing the system.

The impacts of these climate changes scenarios on water allocation levels are presented in Table 1. For each climate change scenario, the variability of water availability is represented with four water allocation states of nature-low, moderately low, moderately high, and high allocation levels. Though the detail is not reported here, the level of allocation associated with each state of nature changes depending on the climate change scenario (e.g., low availability years become more frequent as the climate change scenario moves from the baseline to the severe). A key finding from the basin water-balance modelling is that annual salinity concentrations throughout the Murray-Darling Basin are estimated to increase with the degree of climate change relative to the baseline climate scenario. Similarly, salinity concentration increases are expected to be greater further downstream as flow volume reductions downstream are expected to be greater than reductions upstream.

\section{Irrigation sector economic response model}

Results of several irrigation sector adaptive response modelling exercises were used for this analysis. This includes a model developed to evaluate climate change impacts on the Lower Murray (Connor, et al. [8]). That analysis involved modelling adaptation to reduced and more variable water supply using a twostage model of adjustment with recourse (Danzig, [9]; McCarl et al. [10]). The first stage models the choice of long-run water entitlement and irrigation cropping capital investments. The second stage models the short-run (annual) decisions regarding water application rates, area dewatered on a temporary annual basis, and annual water lease purchases and sales. Short-run decisions vary over states of nature characterising variation in annual water allocation and price. The short-run decisions are conditional on the fixed capital levels chosen in the first stage.

Part of the analysis reported on here involved an extension of Connor [8] in two directions. First, the crop-water production function was updated with a formulation that accounts for the effects of both water stress and salinity on yield, and is consistent with agronomic science and previous research into the economics of salinity management analysing these relationships (Kan et al. [11]; Schwabe et al. [4]). Second, the profit function formulation was extended to include a third stage which involves a weekly choice of how much water to apply based on yield response given weekly varying salinity levels. This stage incorporates weekly marginal economic decisions consisting of comparing the cost of additional water with the benefits of yield reductions from the saltleaching as a result of applying the water.

Solutions are obtained through maximizing regional agricultural profits from irrigated agricultural production given constraints on land, water, and crop mix. 
In the extended model, the following profit function was solved for three subregions within the LMDB:

$$
\begin{aligned}
\pi= & \sum_{s} \operatorname{prob}_{s} *\left(\sum_{w} \sum_{j} \sum_{h} p_{j}^{c} y_{s w j h}-p_{s}^{m}\left(w_{s w j h}^{c}-w_{s}^{a}\right)-p^{f} w_{s}^{a}-v c_{j}\right) * a i_{s j h} \\
& -\sum_{s} \operatorname{prob}_{s} * \sum_{j} \sum_{h} f y c_{j} *\left(a i_{s j h}-a_{j h}\right) \\
& -\left(\sum_{j} \operatorname{cec}_{j}-\sum_{j} \sum_{h} i e c_{j h}\right) * a_{j h}
\end{aligned}
$$

where the choice variables include:

$\mathrm{a}_{j h} \sim$ area (hectares) for crop $j$ using irrigation system $h$;

$\mathrm{ai}_{s j h} \sim$ area (hectares) for crop $j$ using irrigation system $h$ irrigated in state of nature $s$ (as opposed to being fallowed);

$\mathrm{y}_{\text {swjh }} \sim$ contribution to total yield (tonnes) from water applied in week $w$ on crop $j$ using irrigation system $h$ for state of nature $s$;

$w_{\text {swjh }}^{c} \sim$ water (ML) applied in week $w$ to crop $j$ using irrigation system $h$ in state of nature $s$;

and the parameters in the objective function include:

$p_{j}^{c} \sim$ price of $\operatorname{crop} j$

$p_{s}^{m} \sim$ price of water on market in state of nature $s$;

$p^{f} \sim$ delivery cost of initial water allocation;

$w_{s}^{a} \sim$ initial water allocation in state of nature $s ;$

$\mathrm{vc}_{j} \sim$ other variable costs to produce crop $j$;

fyc $_{j} \sim$ future yield costs from under-irrigated perennial crop $j$;

$\operatorname{cec}_{j} \sim$ crop establishment costs for crop $j$

$\operatorname{iec}_{j h} \sim$ irrigation establishment costs for crop $j$ using irrigation system $h$;

prob $_{s} \sim$ probability of state of nature $s$.

\section{Results}

The climate change basin water balance model predicted $13 \%$ and $38 \%$ less flow into the basin for mild and moderate climate change scenarios. These inflow reductions result in even greater $36 \%$ and $47 \%$ average annual allocation reductions to the region as the result of basin water sharing rules. Consider first results of the scenario precluding water trade in which the water use is restricted to regional allocations.

Because there are a range of adaptive responses including improved irrigation efficiency and deficit irrigation, output reductions are only $9 \%$ and $13 \%$ for mild and moderate climate change, much less than the water supply allocation reductions. In the more realistic scenario consistent with Murray Darling Basin institutional rules it is assumed that water can be traded into the region independently of land. Despite high prices, significant amounts are predicted to be imported from lower value production regions. The economically optimal response still involves $3 \%$ and $5 \%$ less output, and $18 \%$ and $27 \%$ less water use 
than in the baseline climate scenario. Regional detail of water use, output, and profit impacts by region is provided in Table 2 for the scenario assuming water trade.

Table 2: $\quad$ Output, water use, and profit impacts of climate change.

\begin{tabular}{lllll}
\hline Scenario & Region & $\begin{array}{l}\text { Water use } \\
(\mathrm{gl})\end{array}$ & $\begin{array}{l}\text { Output } \\
\text { index })\end{array}$ & (yield \\
\hline baseline & Riverland & 47.57 & 11.8 & 304.4 \\
climate 1 & Riverland & 39.35 & 11.48 & 264.2 \\
climate 2 & Riverland & 34.94 & 11.22 & 236.4 \\
baseline & Sunraysia & 59.12 & 11.87 & 385.7 \\
climate 1 & Sunraysia & 48.43 & 11.56 & 333.1 \\
climate 2 & Sunraysia & 43.3 & 11.35 & 298.8 \\
baseline & lower lakes & 14.43 & 11.31 & 59.7 \\
climate 1 & lower lakes & 11.55 & 10.73 & 45.0 \\
climate 2 & lower lakes & 10.38 & 9.87 & 26.7 \\
\hline
\end{tabular}

Table 3 describes regional water use, output and profit impacts that precluding free water trade would have on the region. As can be seen the impact is estimated to be largest on Lower Lakes region where high salinity and low water allocations present the greatest constraints on regional production in absence of ability to import water

Table 3: Output, water use and profit impacts of precluding free water trade.

\begin{tabular}{llrrr}
\hline Scenario & Region & water use change & Output change & Profit change \\
\hline climate 1 & Riverland & $-30.80 \%$ & $-10.02 \%$ & $-9.44 \%$ \\
climate 2 & Riverland & $-39.81 \%$ & $-18.81 \%$ & $-32.97 \%$ \\
climate 1 & Sunraysia & $-12.04 \%$ & $-2.60 \%$ & $-1.98 \%$ \\
climate 2 & Sunraysia & $-14.06 \%$ & $-3.61 \%$ & $-2.95 \%$ \\
climate 1 & lower lakes & $-34.55 \%$ & $-9.97 \%$ & $-12.42 \%$ \\
climate 2 & lower lakes & $-43.74 \%$ & $-19.05 \%$ & $-56.61 \%$ \\
climate 1 & Region & $-21.79 \%$ & $-6.30 \%$ & $-6.01 \%$ \\
climate 2 & Region & $-27.33 \%$ & $-11.23 \%$ & $-20.33 \%$ \\
\hline
\end{tabular}

An additional objective of this analysis was to assess how increasingly salinity may exacerbate the challenge of meeting growing food demand with reduced water supply. As summarised in Table 1, one impact of reduced flow in the Lower Murray is anticipated to be greater salt concentration in the river. To assess the impacts of this higher salinity, water use, output and profit were estimated with for climate scenarios with and without accounting for this higher salinity concentration. For the region as whole, elevated salinity is estimated to increase water use by $0.6 \%$ and $2.7 \%$ and decrease output by $0.2 \%$, and $0.8 \%$ for 
the mild and moderate climate change scenarios respectively. This implies that $7 \%$ and $17 \%$ percent of the estimated total decline in regional output can be attributed to higher salinity in mild and moderate climate change scenarios. There clear regional differences, with much greater impact in the Lower Lakes region where very high concentrations as the result of reduced flow are anticipated.

Table 4: $\quad$ Output, water use and profit impacts of climate induced salinity.

\begin{tabular}{llrrr}
\hline Scenario & Region & $\begin{array}{l}\text { Water } \\
\text { change }\end{array}$ & $\begin{array}{l}\text { Output } \\
\text { change }\end{array}$ & $\begin{array}{l}\text { Profit } \\
\text { change }\end{array}$ \\
\hline climate 1 & riverland & $0.55 \%$ & $-0.17 \%$ & $-0.44 \%$ \\
climate 2 & riverland & $1.82 \%$ & $-0.36 \%$ & $-2.13 \%$ \\
climate 1 & sunraysia & $0.00 \%$ & $0.00 \%$ & $-0.14 \%$ \\
climate 2 & sunraysia & $1.72 \%$ & $-0.09 \%$ & $-0.74 \%$ \\
climate 1 & lower lakes & $3.96 \%$ & $-1.29 \%$ & $-6.66 \%$ \\
climate 2 & lower lakes & $11.36 \%$ & $-6.45 \%$ & $-35.63 \%$ \\
climate 1 & Region & $0.62 \%$ & $-0.20 \%$ & $-0.91 \%$ \\
climate 2 & Region & $2.72 \%$ & $-0.83 \%$ & $-4.78 \%$ \\
\hline
\end{tabular}

Table 5: Percolation, irrigation efficiency and salt leaching impact of climate change.

\begin{tabular}{|c|c|c|c|c|c|}
\hline Scenario & Region & $\begin{array}{l}\text { Percolation } \\
\text { (GL) }\end{array}$ & $\begin{array}{l}\text { Percolation } \\
\text { less } \\
\text { leaching } \\
(\mathrm{GL})\end{array}$ & $\begin{array}{l}\text { Irrigation } \\
\text { efficiency } \\
\& \text { irrigation } \\
\text { efficiency } \\
\text { less } \\
\text { leaching * }\end{array}$ & $\begin{array}{l}\text { Irrigation } \\
\text { efficiency } \\
\text { less } \\
\text { leaching }\end{array}$ \\
\hline baseline & Riverland & 84.3 & 84.3 & $\begin{array}{l}82.3 \% \\
86.1 \%\end{array}$ & $82.30 \%$ \\
\hline climate 2 & Riverland & 48.5 & 40.1 & $(88.5 \%)$ & $88.50 \%$ \\
\hline baseline & Sunraysia & 112.3 & 112.3 & $\begin{array}{l}81.0 \% \\
85.3 \%\end{array}$ & $81.00 \%$ \\
\hline climate 2 & Sunraysia & 63.8 & 58.0 & $(86.6 \%)$ & $86.60 \%$ \\
\hline baseline & lower lakes & 27.1 & 27.1 & $\begin{array}{l}81.2 \% \\
79.8 \%\end{array}$ & $81.20 \%$ \\
\hline climate 2 & lower lakes & 21.0 & 12.7 & $(87.8 \%)$ & $87.80 \%$ \\
\hline baseline & Region & 223.6 & 223.6 & $\begin{array}{l}81.5 \% \\
85.0 \%\end{array}$ & $81.5 \%$ \\
\hline climate 2 & Region & 133.3 & 113.8 & $(87.5 \%)$ & $87.5 \%$ \\
\hline
\end{tabular}

* Value in parenthesis are irrigation efficiency less leaching.

Climate change is anticipated to effect volumes of water percolating below irrigation in two potentially offsetting ways. The incentives created by greater water scarcity and higher water price should motivate increased efficiency and reduced percolation. The higher salinity concentrations associated with less flow 
should motivated increased leaching of salts and greater percolation. As shown in Table 5, the net result for the region as a whole is less percolation and greater irrigation efficiency. The effect is uneven across the region with significant increase in leaching volumes anticipated in the Lower Lakes where greatest salinity level increases are anticipated under climate change.

One significant third party impact of the improved irrigation efficiency is reduced reliability of third party water rights. Because regional rules allow trade in the full volume of water diverted, efficiency savings can be are often sold to third parties for consumptive. This reduces return flows that would have formed part of third party water rights or environmental flows. The efficiency savings for the moderate climate change scenario estimated here represents $4 \%$ of baseline water use. Given current allocation rules this amount would be shared $(80 \% / 20 \%)$ as reductions in environmental flow and consumptive use rights. A positive third party impact of reduced percolation is reduced river salt loading. Doble et al. [12] found that this effect is time delayed by decades and of lesser magnitude than the concentration effect of reduced flow.

\section{Summary and conclusions}

This article assessed the impact of climate change on capacity to supply food for the Lower Murray irrigation region in Australia. The region is a good case study as it is confronted with reduced water supply and rising salinity as a consequence of climate change. Results suggest that reduced water supply is likely to reduce the amount of food supplied from the region, but food supply reduction is likely to be less than proportional to water supply decline as a result of adaptation opportunities to use water more efficiently. Salinity impacts of reduced water supply exacerbate the impacts of increased water scarcity modestly, as more water is required to leach increased salinity associated with low flows in climate scenarios. The institutional arrangements in the region allowing water trade have a very significant impact on reducing adverse impacts of climate change. Externality impacts of water trade are found to have positive water quality and negative water right reliability, and environmental flow impacts.

\section{References}

[1] Anderson, K., Dimaranan, B., Hertel, T., Martin, W. Asia-Pacific food markets and trade in 2005: a global, economy-wide perspective The Australian Journal of Agricultural and Resource Economics 41 (1) , 19-44 doi:10.1111/1467-8489.00002 (1997).

[2] Rosegrant, M. Water resources in the twenty first century: challenges and implications for action. International Food Policy Research Institute. Food, Agriculture, and the Environment Discussion Paper 20 (March, 1997).

[3] Young, M. D. and J. C. McColl. Robust Reform: The Case for a New Water Entitlement System for Australia, Australian Econ. Rev., 36(2), 225234, doi:10.1111/1467-8462.00282 (2003). 
[4] Schwabe, K.A., I. Kan, and K.C. Knapp. Drainwater Management for Salinity Mitigation in Irrigated Agriculture, Amer. J. Agr. Econ., 88(1), 135-149 (2006).

[5] MDBMC, Basin Salinity Management Strategy 2001-2015, Murray Darling Basin Ministerial Council, Canberra. (2001).

[6] Overton, I., Modelling Floodplain Inundation on a Regulated River: Integrating GIS, Remote Sensing and Hydrological Models, River Research and Applications (Forthcoming) (2004).

[7] Kirby, M, Evans, R, Walker, G. et al. The shared water resources of the Murray-Darling Basin. Murray-Darling Basin Commission Report, Canberra (2006).

[8] Connor, J. M., Kirby, K., Schwabe, A., Lukasiewicz and D. Kaczan. Impacts of reduced water availability on lower Murray irrigation, Australia. Socio-Economics and the Environment in Discussion (SEED). CSIRO Working Paper Series Number 2008-02. February 2008.

[9] Danzig G. B. Linear programming under uncertainty, Management Science 1:197-206 (1955).

[10] McCarl, B. A., Dillion, C. R., Keplinger, K. O. et al. Limiting pumping from the Edwards Aquifer: an economic investigation of proposal, water markets, and spring flow guarantees. Water Resources Research 34(4): 257-1268 (1999).

[11] Kan, I., K. A. Schwabe, and K. C. Knapp. Microeconomics of Irrigation with Saline Water, J. Agr. Resource Econ., 27(1), 16-39. (2002).

[12] Doble, R., J. Connor, M. Stenson, A. Elmahdi, I. Jolly, M. Miles and G. R. Walker. Future landscape scenarios in the lower River Murray Corridor and their implications for river salinity and floodplain health. Third International Salinity Forum. Adelaide, Australia. March 31-April 4, 2008. 